\title{
Role of the gerA operon in L-alanine germination of Bacillus licheniformis spores
}

\author{
Irene S Løvdal ${ }^{1,2,4}$, Cecilie From² , Elisabeth H Madslien ${ }^{2,3}$, Kristin Cecilia S Romundset ${ }^{2}$, Elin Klufterud ${ }^{2,5}$, \\ Jan Thomas Rosnes ${ }^{1}$ and Per Einar Granum ${ }^{2 *}$
}

\begin{abstract}
Background: The genome of Bacillus licheniformis DSM 13 harbours three neighbouring open reading frames showing protein sequence similarities to the proteins encoded from the Bacillus subtilis subsp. subtilis 168 gerA operon, GerAA, GerAB and GerAC. In B. subtilis, these proteins are assumed to form a germinant receptor involved in spore germination induced by the amino acid L-alanine.

Results: In this study we show that disruption of the gerAA gene in B. licheniformis MW3 hamper L-alanine and casein hydrolysate-triggered spore germination, measured by absorbance at $600 \mathrm{~nm}$ and confirmed by phase contrast microscopy. This ability was restored by complementation with a plasmid-borne copy of the gerA locus. Addition of D-alanine in the casein hydrolysate germination assay abolished germination of both $B$. licheniformis MW3 and the complementation mutant. Germination of both B. licheniformis MW3 and the gerA disruption mutant was induced by the non-nutrient germinant $\mathrm{Ca}^{2+}$-Dipicolinic acid.
\end{abstract}

Conclusions: These results demonstrate that the B. licheniformis MW3 gerA locus is involved in germination induced by L-alanine and potentially other components present in casein hydrolysate.

\section{Background}

Germination of dormant Bacillus spores and subsequent outgrowth can be induced by various nutrients (amino acids, purine nucleosides, sugars, ions and combinations of these) recognised by receptor proteins encoded by the gerA family operons [1-3] and located in the inner membrane of the spore [4-7]. One or several germination receptor operons have been detected in the genomes of almost all spore formers, and supported by studies of different mutants it has been concluded that spores respond to germinants via receptors diverged from common ancestor(s) ([6] and references therein). Studies of receptor/germinant interactions have so far mainly been focusing on species belonging to Bacillus cereus, Bacillus subtilis, Bacillus megaterium and Bacillus anthracis [3,8-16]. Bacillus licheniformis, another Gram-positive, spore forming soil bacterium closely related to B. subtilis [17], has on the other hand gained

\footnotetext{
* Correspondence: pereinar.granum@nvh.no

2Departement of Food Safety and Infection Biology, Section for Food Safety, Norwegian School of Veterinary Science, Ullevålsveien 72, P. Box 8146 Dep., N-0033 Oslo, Norway

Full list of author information is available at the end of the article
}

much less attention. B. licheniformis is a frequent contaminant of foods, and is a common spoilage organism of dairy products [18-20], bread [21,22], packaged meats [23] and canned goods [24]. It has previously been considered non-pathogenic, and has been widely used in the industry for production of enzymes, antibiotics and biochemicals [25-27]. However, B. licheniformis-associated bovine abortion [28,29], implant infection [30], corneal ulcer [31], bacteraemia sepsis [32] and food poisoning $[33,34]$ raise the question of its pathogenic potential. Some strains of $B$. licheniformis associated with human disease are capable of producing lichenysin A, a surfactin-like toxin [34,35]. Due to its association with food-borne illness and spoilage, and its ability to undergo sporulation, [17,36-38], extended knowledge about the germination apparatus of $B$. licheniformis is of general interest. To ensure microbiological safe food production of durable foods produced by relatively mild heat treatment, there is an obvious need for more information on spore forming bacteria.

Based on existing literature, B. subtilis could be considered as the model organism for germinant receptor studies. It was through early studies of germination 
defective mutants, that the theory of a L-alanineinduced germinant receptor was proposed [8]. Later studies identified the ger $A$ locus as a tricistronic operon weakly expressed during sporulation, and that the polypeptide products of gerA probably formed a membrane associated complex [39-41]. The products of each of the three genes of gerA were later named GerAA, GerAB and GerAC, and were demonstrated to be simultaneously required for the spore to respond to L-alanine as sole germinant [2]. Genome sequence analysis and germination experiments of different mutants further identified four other tricistronic ger $A$ homologs for $B$. subtilis; gerB, gerK, yndDEF and yfkQRT [10]. Receptors encoded by two of these operons, gerB and gerK, are confirmed functional when acting cooperatively with each other or with gerA $[10,15]$.

Homologous genes of germinant receptors belonging to the gerA family have been found in most spore formers, although the exact number, organisation and corresponding response germinant may vary for different species and even strains $[3,42,43]$. B. licheniformis ATCC 14580 is also predicted to possess potential germinant receptor proteins belonging to both the GerA and the GerK clades [44]. The GerAA, GerAB and GerAC protein sequences of $B$. licheniformis ATCC14580 are closely related to the protein sequences of the corresponding germinant receptor subunits of Bacillus subtilis subsp. subtilis 168 . These are in B. subtilis encoded by the ger $A$ operon, ger $A A$, ger $A B$ and ger $A C$. Since $B$. subtilis ger $A$ germination is triggered by $\mathrm{L}$-alanine [2,15], it is plausible that the $B$. licheniformis ger $A$ operon also is involved in L-alanine germination. It has earlier been documented that spores of $B$. licheniformis from different strains actually respond to L-alanine as germinant [45-47], but to our knowledge, there are no functional studies of receptor/germinant interactions of strains belonging to $B$. licheniformis.

Mutational studies of $B$. licheniformis, including the fully sequenced B. licheniformis ATCC 14580/DSM 13 strain $[48,49]$, have long been a challenge, most likely due to their possession of a restriction apparatus destroying foreign DNA [48-50]. The construction of a more easily transformable mutant, $B$. licheniformis MW3, has largely overcome this challenge [50].

In order to facilitate the understanding of germinant/ receptor interactions in B. licheniformis, we have constructed disruption and complementation mutants of the gerAA locus in B. licheniformis MW3. Spores of these mutants have been studied in germination assays with L-alanine, casein hydrolysate and the non-nutrient germinant $\mathrm{Ca}^{2+}$ Dipicolinic acid $\left(\mathrm{Ca}^{2+} \mathrm{DPA}\right)$. These studies reveal that gerA is a main germinant receptor complex of B. licheniformis recognising amino acid(s), and supports the view that L-alanine is an important nutrient-germinant for this species.

\section{Results and Discussion \\ Construction of the disruption and complementation mutants}

To elucidate the role of the hypothetical GerA proteins during spore germination, a disruption mutant of the gerAA locus in B. licheniformis MW3 was constructed. $B$. licheniformis MW3 was used as target strain due to its superior transformability compared to its fully sequenced parent strain DSM 13 [50]. The gerAA mutant, NVH-1307, was constructed so that a part of the gerAA gene was substituted with a spectinomycin resistance cassette. This will cause the mutant to acquire spectinomycin resistance, and in addition, affect a potential phenotype related to the disrupted gene. If the target gene is part of an operon, which is the case of gerAA, downstream transcripted genes will also be affected, and the receptor non functional. Sequence analysis showed that in addition to harbouring the spectinomycin cassette in the ger $A A$ locus, NVH-1307 also harboured two additional mutations (one base substitution and one base deletion) in the gerAA locus. These mutations were most likely acquired during PCR amplification of the fragments used to construct the disruption vector (pMAD_Sp $\left.{ }^{\mathrm{R}} \Delta g e r A A\right)$. These mutations were "accepted" (not corrected) due to their location in the gene targeted for disruption. However, in construction of the plasmid used for gerAA complementation, a polymerase with a higher expected fidelity was applied to limit the risk of such mutations. Sequence analysis of the complementation plasmid pHT315_MW3gerA revealed no mutations in the amplified ger $A$ operon when compared to the sequence of Veith et al.[48].

Genetic modification studies have shown that the germination rates could be significantly increased when specific germinant receptors are over-expressed in $B$. subtilis [51]. Thus, expression of germinant receptors is apparently not optimised for maximal spore germination, forwarded as a possible evolutionary strategy to prevent premature germination at nutrient conditions inadequate for sustained vegetative growth [3]. Very high levels of receptor expression could on the other hand have a negative effect on the sporulation process [51]. In such cells, the forespore lyses during the process of sporulation, perhaps as a result of premature forespore germination [51]. An appropriate evolutionary adaptation of germinant receptor expression/regulation is thus crucial to allow the cyclic transition between sporulation and germination upon environmental changes. In the construction of the complementation mutants in our study, certain precautions were therefore 
taken to avoid extensive over-expression of the complemented germinant receptor genes. By including some of the flanking regions of the ger $A A, \operatorname{ger} A B$ and ger $A C$ fragment in the complementation plasmid, we wanted to maintain the native regulatory elements of this locus. In addition, a shuttle-vector with an expected low or moderate copy number was sought as a basis for the complementation plasmid. To our knowledge, there is no shuttle-vector available for $B$. licheniformis where the copy number is demonstrated to be low or moderate. However, Arantes and Lereclus [52] have constructed the pHT315 E. coli/B. thuringiensis shuttle-vector, with a copy number of $\sim 15$ per equivalent $B$. thuringiensis chromosome. This vector has successfully been used in germinant receptor complementation studies in $B$. megaterium [53], and was thus considered as a reasonable choice for $B$. licheniformis. Despite that this vector has shown to be stably maintained in $B$. thuringiensis and $B$. megaterium without a selective pressure [52,54], the antibiotic erythromycin had to be included to ensure persistence of the complementation plasmid during sporulation of the $B$. licheniformis complementation mutant NVH-1311. This could be due to a different segregation stability of the vector in $B$. licheniformis. Another possibility is that there is a potential elevated risk of plasmid curing due to sporulation at a high temperature. Sporulation of $B$. licheniformis MW3, NVH1307 and $\mathrm{NVH}-1311$ were performed at $50{ }^{\circ} \mathrm{C}$ since a pilot study showed that sporulation at this temperature was faster, yielded more stable spores (less spontaneous germination) and a higher percentage of phase bright spores (results not shown).

\section{Disruption of gerAA abolish L-alanine and casein hydrolysate induced germination}

Decrease in absorbance at $~ 600 \mathrm{~nm}\left(\mathrm{~A}_{600}\right)$ is used as a convenient method to monitor and compare germination of different spore populations $[55,56]$. A fall in absorbance reflects a change in the refractive index (light scattering) of the multiple individual spores in a suspension, associated with germination events such as the excretion of spore's depot of $\mathrm{Ca}^{2+}$-DPA, followed by water influx, cortex degradation and core swelling [51,56-59]. Figure 1 shows a representative experiment where different strains of heat activated $\left(65^{\circ} \mathrm{C} 20 \mathrm{~min}\right)$ spores (in Phosphate buffer) are supplemented with the germinant L-alanine. At these conditions, a clear change in absorbance was observed for spores of wild type (MW3) and wild type complementation mutant (NVH1311) supplemented with L-alanine. Less than a $5 \% / \mathrm{h}$ decrease in absorbance was observed for spores of the disruption mutant (NVH-1307). Phase-contrast images captured at the end of the germination assay (Figure 2), a technique where germinated and dormant spores appear dark and white/bright respectively $[56,59,60]$, supports the absorbance measurements showing that spores of the wild type (MW3) and wild type complementation mutant (NVH-1311) germinate with L-alanine. No apparent increase in number of phase dark spores was observed for spores of the deletion mutant (NVH-1307) supplemented with L-alanine, or the negative controls. Together with the absorbance measurements, this shows that the introduced disruption of the gerAA gene abolishes the ability of $B$. licheniformis MW3 to use L-alanine as a germinant. The fact that the NVH-1311 complementation mutant showed a similar L-alanine triggered germination phenotype as the wild type spores, supports the hypothesis that an undisrupted copy of the ger $A A$, ger $A B$ and ger $A C$ genes, with flanking elements, are required for normal germination of $B$. licheniformis MW3 at these conditions. These findings were also supported by experiments performed with an alternative germination buffer; $50 \mathrm{mM}$ Tris $\mathrm{HCl} \mathrm{pH} 7.4$ $10 \mathrm{mM} \mathrm{KCl} \mathrm{(E.} \mathrm{Klufterud,} \mathrm{C.} \mathrm{From;} \mathrm{unpublished}$ results).

An earlier study where germination in seven strains of B. licheniformis was investigated, showed that out of 24 amino acids tested, only L-alanine, L-cysteine and Lvaline markedly stimulated germination [46]. In general, a greater germination response with L-alanine than with L-cysteine and L-valine was observed [46]. To assay the germination response of MW3, NVH-1307 and NVH1311 to several amino acids, casein hydrolysate was used. Casein hydrolysate consists of a mixture of amino acids made from acid hydrolyzation of the milk protein casein and has been used as a germinant for Clostridium bifermentans and B. cereus in earlier studies [61-63]. In our study, casein hydrolysate proved to be a potent germinant for $B$. licheniformis, giving a rapid germination response $(\sim 70 \%$ phase dark spores as visualised by phase contrast microscopy) both for the wild type MW3 and the complementation mutant $\mathrm{NVH}-1311$. The mutant NVH-1307, which most likely lacks a gerA receptor, did not show any germination response in casein hydrolysate (Figure 3).

D-alanine is a well-known inhibitor of L-alanine germination of $B$. subtilis and $B$. licheniformis $[64,65,46,15,66]$. D-alanine has also been shown to reduce $\mathrm{L}$-valine induced germination of $B$. subtilis $[15,66]$, but we are not aware of studies reporting the effect of D-alanine on L-valine induced germination of B. licheniformis. In order to abolish germination by Lalanine present in the casein hydrolysate, we added Dalanine in some of the above experiments. In these experiments, the germination response of both MW3 and NVH-1311 was hardly measurable (results not shown), indicating that L-alanine through its triggering of the gerA receptor is an important germinant of $B$. 


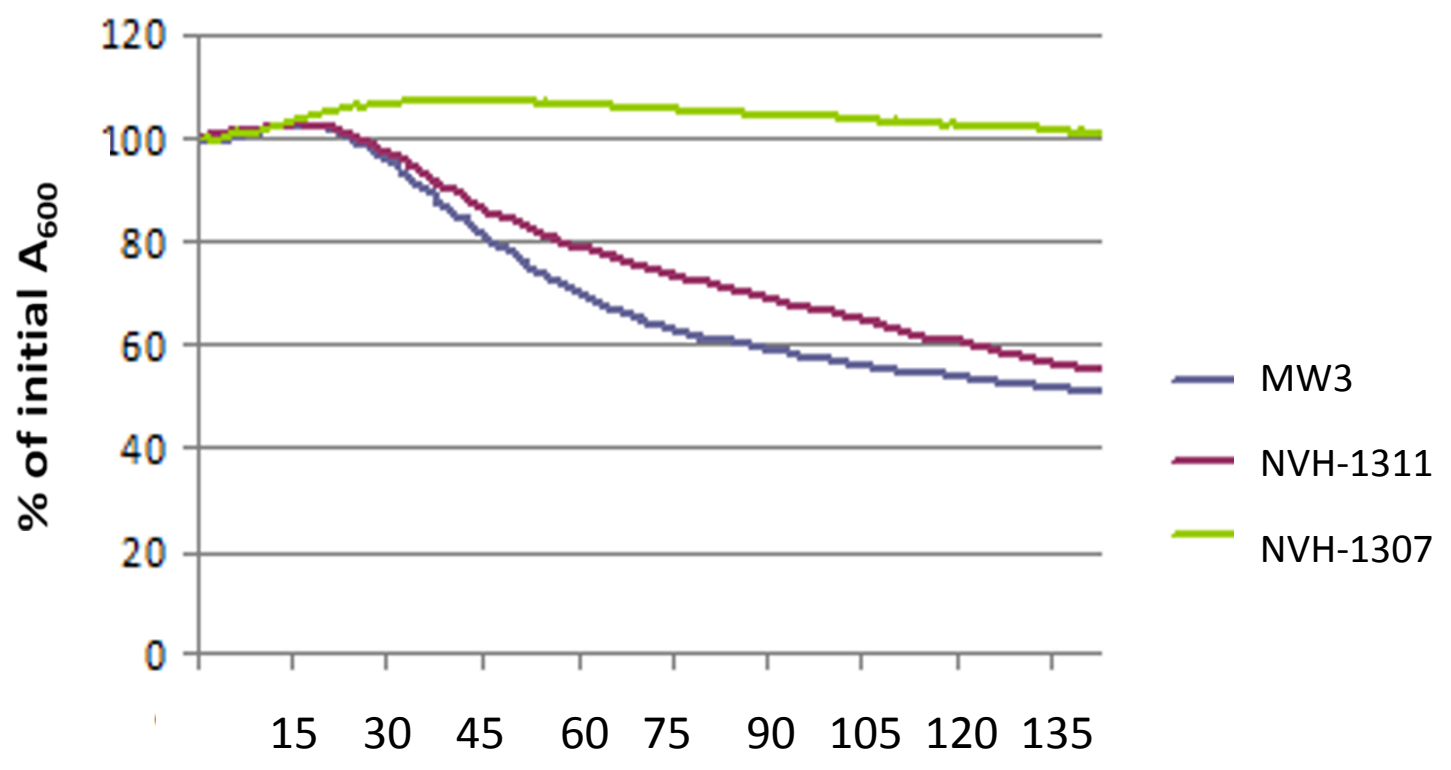

Time (min)

Figure 1 Germination of $\boldsymbol{B}$. licheniformis with L-alanine. Germination is followed as a change in initial absorbance at $600 \mathrm{~nm}\left(\mathrm{~A}_{600}\right)$ of phase bright spores in K-phosphate buffer pH 7.2 at $30^{\circ} \mathrm{C}$ after addition of $100 \mathrm{mM} \mathrm{L}$-alanine. Complete germination (>99\% phase dark spores as observed by phase contrast microscopy) was observed at $\sim 40 \%$ of initial $A_{600}$. The results shown are representative of experiments performed in duplicate on two individual spore batches repeated at least twice.

licheniformis. The contribution to germination of the remaining amino acids in the casein hydrolysate when D-alanine was present, appear to be minimal. Although one can not rule out that D-alanine also inhibits the effect of other amino acids present in casein hydrolysate (e.g. L-valine), all the findings support the view that gerA and L-alanine constitute one of the main germination pathways of B. licheniformis.

\section{Germination of $B$. licheniformis with $\mathrm{Ca}^{2+}$-DPA}

In order to by-pass the spore germination receptor apparatus, experiments using exogenous $\mathrm{Ca}^{2+}$-DPA to trigger germination of spores of $B$. licheniformis MW3 and the mutant strain NVH-1307 were performed. In $B$. subtilis spores, $\mathrm{Ca}^{2+}$-DPA induced germination is believed to act through activation of the cortex lytic enzyme CwlJ, without any requirement of functional germinant receptors [10,67]. Bioinformatic analysis of complete genomes of different spore formers has shown that also $B$. licheniformis contains a B. subtilis homologous $c w l J$ gene [43]. If the germination apparatus of $B$. licheniformis spores is similar to that of its close relative $B$. subtilis, the wild type and disruption mutant of $B$. licheniformis should exhibit a similar germination response as $B$. subtilis to exogenous $\mathrm{Ca}^{2+}$-DPA. The
DPA concentration needed to trigger germination in $B$. subtilis is $\sim 20-60 \mathrm{mM}$, supplemented together with equal (or excess) amounts of $\mathrm{Ca}^{2+}$ (allowing formation of a 1:1 chelate of calcium and dipicolinic acid) [10]. Also spores of $B$. cereus and $B$. megaterium germinate when exposed to $\mathrm{Ca}^{2+}$-DPA $[68,69]$. For $B$. cereus it has been shown that a final level of $60 \mathrm{mM} \mathrm{Ca}^{2+}$-DPA is sufficient to ensure germination [69]. In our experiments (Table 3), B. licheniformis spores of MW3, the mutant NVH-1307 and B. subtilis spores of strain B252 (used as a positive control) germinated effectively after 3 hours exposure in room temperature at a final concentration of $80 \mathrm{mM} \mathrm{DPA}$ and $100 \mathrm{mM} \mathrm{CaCl}_{2}$. Further, at $45 \mathrm{mM}$ DPA $50 \mathrm{mM} \mathrm{CaCl}_{2}$ spores of $B$. cereus ATCC 14579 germinated effectively whilst spores of $B$. subtilis strain B252 showed a moderate germination response. B. licheniformis MW3 and NVH-1307 exhibited a weak germination response even after a prolonged exposure of $\sim 21 \mathrm{~h}$ at these concentrations. At $20 \mathrm{mM}$ DPA 30 $\mathrm{mM} \mathrm{CaCl} 2$ B. cereus ATCC 14579 germinated moderately whilst spores of MW3, NVH-1307 and B. subtilis B252 did not germinate (Table 3). Earlier $\mathrm{Ca}^{2+}$-DPA germination studies with other $B$. licheniformis strains in our collection have yielded similar results with less effective $\mathrm{Ca}^{2+}$-DPA induced germination compared to $B$. 


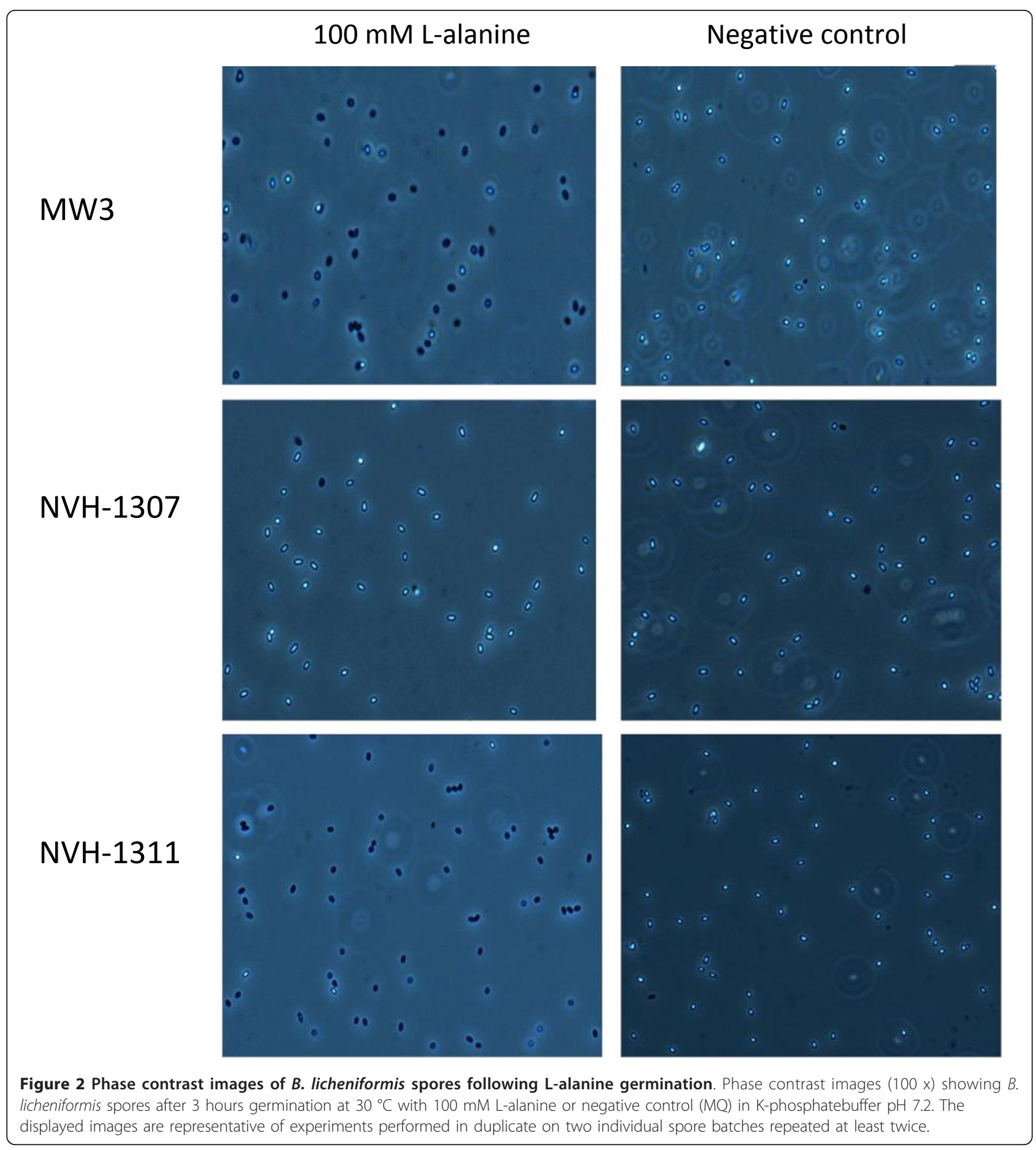

cereus ATCC 14579 and spores of B. pumilus (results not shown). Reasons for a reduced sensitivity to $\mathrm{Ca}^{2}$ ${ }^{+}$-DPA as a non-nutrient germinant in B. licheniformis MW3 spores compared to spores of some other spore forming bacteria is unknown. It might be that the relationship between $\mathrm{Ca}^{2+}$ and DPA or the concentration of the chelate is not ideal for $B$. licheniformis germination.
Another possibility is that a so far uncharacterised nonnutrient inducing germinant or a mixture of DPA with other ions than $\mathrm{Ca}^{2+}$ is needed for effective CwlJ mediated germination of $B$. licheniformis. It has been shown in earlier studies that for instance strains of $B$. megaterium also germinate in mixtures with other ions than $\mathrm{Ca}^{2+}[70]$. More information on CwlJ and other 


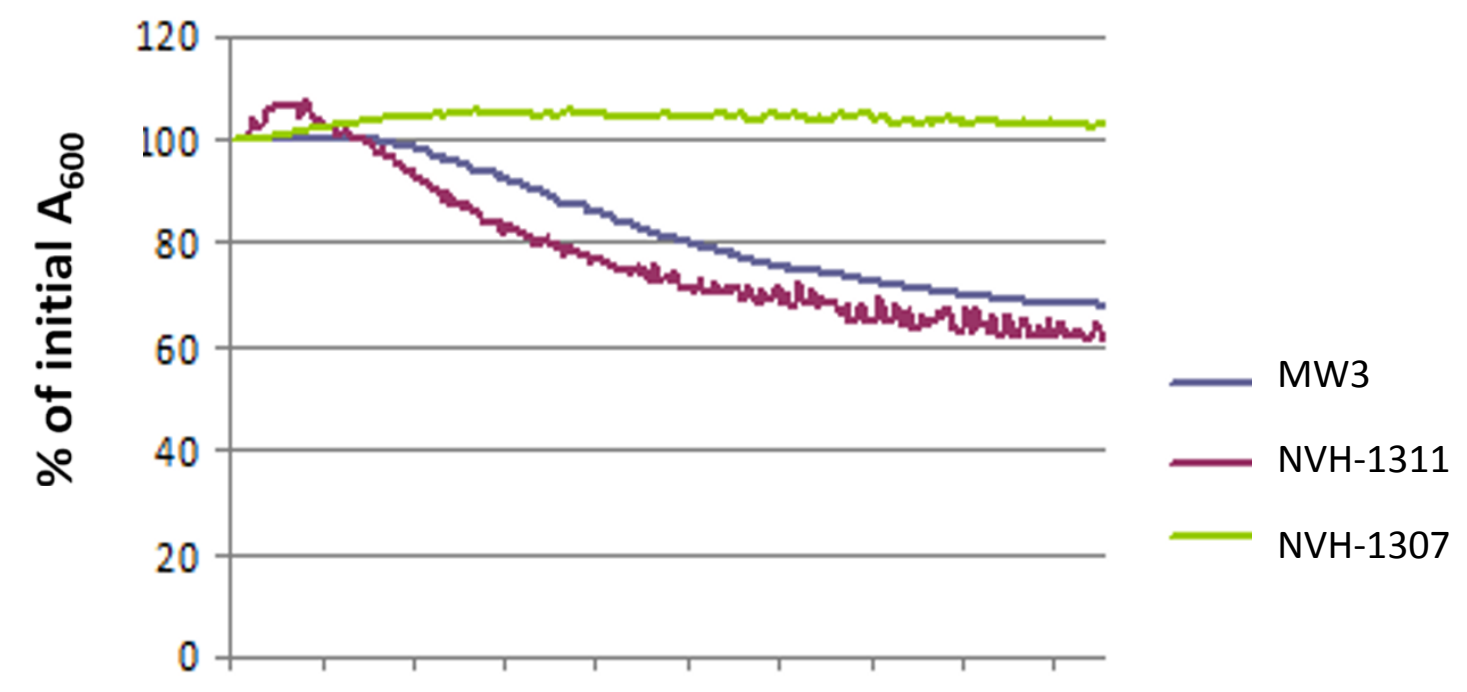

$15 \quad 30 \quad 45 \quad 60 \quad 75 \quad 90 \quad 105120135$

Time ( $\min )$

Figure 3 Germination of $\boldsymbol{B}$. licheniformis with casein hydrolysate. Germination is followed as a change in initial absorbance at $600 \mathrm{~nm}$ ( $\left.A_{600}\right)$ of phase bright spores in Tris $\mathrm{HCl}$ buffer $\mathrm{pH} 7.4$ at $30{ }^{\circ} \mathrm{C}$ after addition of $1 \%(\mathrm{w} / \mathrm{v})$ casein hydrolysate. Complete germination (>99\% phase dark spores as observed by phase contrast microscopy) was observed at $\sim 40 \%$ of initial $\mathrm{A}_{600}$. The results shown are representative of experiments performed in duplicate on two individual spore batches repeated at least twice.

enzyme interactions with $\mathrm{Ca}^{2+}$-DPA is needed to get a clear view on which mechanisms form the basis for the different effects of $\mathrm{Ca}^{2+}$-DPA germination in $B$. licheniformis, B. cereus and B. subtilis. Further characterisation of $\mathrm{Ca}^{2+}$-DPA dependent germination of $B$. licheniformis is currently carried out by our group.

\section{Conclusions}

As demonstrated by genetic mutation and complementation analysis, this study reveals that the ger $A A$ gene in $B$. licheniformis MW3 has a fundamental role in germination triggered by L-alanine and casein hydrolysate. We also show that D-alanine is an important inhibitor in $B$. licheniformis amino acid-induced germination. Further, both wild type and the ger $A$ A disruption mutant germinated effectively when exposed to appropriate levels of the non-nutrient germinant $\mathrm{Ca}^{2+}$-DPA which by-pass the spore receptor apparatus. However, effective germination with $\mathrm{Ca}^{2+}$-DPA seems both strain and species specific. In order to understand and potentially control the germination behaviour of $B$. licheniformis spores, disclosure of factors involved in the transition from a dormant spore to a metabolically active proliferating cell is of prime importance. Although complete elucidation of the function and cooperation of the different germinant receptors are rather laborious, this study has taken a step in the direction of obtaining more knowledge about this less studied species. The availability of both disruption and complementation mutants will facilitate further research on the function of the GerA receptor of B. licheniformis MW3, as well as its potential involvement in germination triggered by alternative nutrients and cooperation with other germinant receptors. Further bioinformatic and

Table $3 \mathrm{Ca}^{2+}$-DPA germination in selected Bacillus spp

\begin{tabular}{|c|c|c|c|c|c|}
\hline \multicolumn{2}{|c|}{ Concentration (mM) } & \multicolumn{4}{|c|}{ Germination $^{a}$} \\
\hline DPA & $\mathrm{CaCl}_{2}$ & B. licheniformis MW3 & B. licheniformis NVH-1307 & B. subtilis B252 & B. cereus ATCC 14579 \\
\hline 80 & 100 & $\sim 70 \%$ & $\sim 70 \%$ & $>99 \%$ & $N T^{b}$ \\
\hline 45 & 50 & $\sim 10-20 \%$ & $\sim 10-20 \%$ & $\sim 50 \%$ & $>99 \%$ \\
\hline 20 & 30 & $<5 \%$ & $<5 \%$ & $<5 \%$ & $\sim 50 \%$ \\
\hline
\end{tabular}

${ }^{a}$ described as an approximate percentage of phase dark spores after screening of microscopic slides by phase contrast microscopy (100x) after 3 hours exposure in room temperature. Performed in duplicate on two individual spore batches and repeated at least twice.

${ }^{\mathrm{b}} \mathrm{NT}$; Not Tested 
phenotypic investigations are in progress in our laboratory and might eventually provide insight relevant for improved spore decimation techniques by the use of induced germination.

\section{Methods}

\section{Bacterial strains and DNA extraction}

The strains used in this study were $B$. licheniformis MW3 [50], B. subtilis B252 [71] and the B. cereus typestrain ATCC 14579 [72,73] (Table 1). B. licheniformis MW3 is a mutant created from B. licheniformis DSM13 (isogenic to ATCC 14580) with targeted deletions of the $h s d R$ loci of two type I restriction modification systems making the strain readily transformable. B. licheniformis MW3 was used as host for creating disruption and complementation mutants of the gerA locus. When not stated otherwise, bacteria were cultured at $37{ }^{\circ} \mathrm{C}$ on LB agar or broth containing appropriate selective antibiotics (Table 1). Genomic DNA for PCR amplifications and sequencing was extracted from $B$. licheniformis MW3 and B. licheniformis $\mathrm{NVH}-1307$ by a method slightly modified from [71], as follows. An overnight culture was transferred to fresh growth medium and grown at $37{ }^{\circ} \mathrm{C}$, 225 rpm (HT-Infors AG CH-4103, Bottmingen, Switzerland), to turbidity (4-5 h). Cells from $1 \mathrm{ml}$ culture was harvested by centrifugation $(3 \mathrm{~min}$ at $16.100 \times g)$, and the pellet was frozen at $-20^{\circ} \mathrm{C}$. Thawed pellet was resuspended in $495 \mu \mathrm{l} \mathrm{SET} \mathrm{buffer}(75 \mathrm{mM} \mathrm{NaCl}, 25 \mathrm{mM}$ EDTA, $20 \mathrm{mM}$ Tris, pH 7.5) and $50 \mu \mathrm{l} 10 \mathrm{mg} / \mathrm{ml} \mathrm{lyso-}$ zyme before incubation at $37{ }^{\circ} \mathrm{C}$ for $1 \mathrm{~h}$. Further, $50 \mu \mathrm{l}$ $10 \%$ sodium dodecyl sulfate and $5 \mu \mathrm{l} 25 \mathrm{mg} / \mathrm{ml}$ proteinase $\mathrm{K}$ was added, and the sample was incubated at $50^{\circ}$ $\mathrm{C}$ for $2 \mathrm{~h}$. At room temperature (RT), the sample was mixed with $200 \mu \mathrm{l} 5 \mathrm{M} \mathrm{NaCl}$ and $700 \mu \mathrm{l}$ of chloroformisoamyl alcohol (24:1), and incubated with frequent inversions for $30 \mathrm{~min}$. The aqueous phase was separated by centrifugation $(20-30 \mathrm{~min}$ at $16.100-20.800 \times g)$, transferred to a fresh tube, and DNA was precipitated by addition of an equal volume of isopropanol followed by centrifugation $(20 \mathrm{~min}$ at $16.100-20.800 \times g)$. The precipitate was washed with $70 \%$ ethanol and centrifuged (15 $\mathrm{min}$ at $16.100-16.500 \times g$ ), and the supernatant was removed before the precipitate was left to air dry. DNA was resuspended in $100 \mu 10 \mathrm{mM}$ Tris $\mathrm{HCl}$ buffer ( $\mathrm{pH}$ 8.5). Plasmid DNA was purified according to the manual provided with the Plasmid Mini/Midi kits $\left(\right.$ QIAGEN $\left.^{\circledR}\right)$.

\section{Preparation and transformation of $B$. licheniformis electrocompetent cells}

Electrocompetent $B$. licheniformis was prepared and transformed by a modified version of the protocol described by Mahillion et al.[74] as follows. A preculture in Brain Heart Infusion broth (BHI) (Oxoid, Cambridge, United Kingdom) was grown overnight at $37{ }^{\circ} \mathrm{C}$, and 1 $\mathrm{ml}$ was used to inoculate $200 \mathrm{ml}$ pre-warmed $\mathrm{BHI}$ in a 1 1 Erlenmeyer. The culture was incubated 4 to $5 \mathrm{~h}$ at $37^{\circ}$ $\mathrm{C}$ and $150 \mathrm{rpm}$ (HT-Infors AG CH-4103, Bottmingen, Switzerland) until $\mathrm{A}_{600}$ of 0.9-1.0 was reached (Shimadzu UV-VIS 160A, Shimadzu Europa GMBH). Cells were pelleted and washed twice with $200 \mathrm{ml}$ RT autoclaved MilliQ water (MQ) by 15 min centrifugations at 3.300 and $10.400 \times g$. The pellet was resuspended in a $10 \mathrm{ml}$ filter sterilised solution of freshly prepared polyethylene glycol (PEG) 6000 (Merck, Darmstadt, Germany), made by dissolving $40 \mathrm{~g}$ PEG6000 in $100 \mathrm{ml}$

Table 1 Strains and plasmids used in this study

\begin{tabular}{|c|c|c|}
\hline strain or plasmid & description, phenotype or genotype relevant for this study ${ }^{a}$ & reference \\
\hline \multicolumn{3}{|l|}{ Strains } \\
\hline $\begin{array}{l}\text { Escherichia coli } \\
\text { TOP10 }\end{array}$ & One Shot ${ }^{\circledR}$ TOP10 electro/chemically competent E. coli for cloning & Invitrogen \\
\hline MW3 & Bacillus licheniformis DSM13 ( $\Delta h s d R 1, \Delta h s d R 2)$ & [50] \\
\hline NVH-1307 & B. licheniformis MW3 $\triangle g e r A A .: s p c . S p^{R}$. & This study \\
\hline $\mathrm{NVH}-1311$ & NVH-1307 with pHT315_MW3gerA. Sp ${ }^{R}$ and $\mathrm{Em}^{\mathrm{R}}$. & This study \\
\hline ATCC 14579 & Bacillus cereus type strain & {$[72,73]$} \\
\hline B252 & Bacillus subtilis isolated from tap water & [71] \\
\hline \multicolumn{3}{|l|}{ Plasmids } \\
\hline PMAD & E. coli/B. licheniformis shuttle plasmid. $A p^{\mathrm{R}}, \mathrm{Em}^{\mathrm{R}}$, ori Bacillus $^{\mathrm{ts}}$ and $p c l p B-b g a B$ & [75] \\
\hline pMAD_Sp ${ }^{R}$ & pMAD-derivate supplemented with a $S p^{R}$ cassette in the Sall site. $A p^{R}, E m^{R}, S p^{R}$, ori Bacillus $^{\text {ts }}$ and $p c l p B$-bgaB & [76] \\
\hline pMAD_Sp ${ }^{\mathrm{R}} \triangle g e r A A$ & 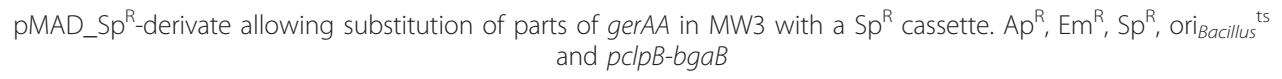 & This study \\
\hline pHT315 & E. coli/B. licheniformis shuttle plasmid. $A p^{R}$ and $\mathrm{Em}^{\mathrm{R}}$ & [52] \\
\hline pHT315_MW3gerA & pHT315-derivate containing gerA fragment ${ }^{b}$ amplified from MW3 DNA template. $A p^{R}$ and $\mathrm{Em}^{\mathrm{R}}$ & This study \\
\hline
\end{tabular}


MQ. Following $15 \mathrm{~min}$ centrifugation at $4.080 \times g$, cells were resuspended in $0.5-1 \mathrm{ml}$ of the PEG6000/MQ solution, aliquoted $(100 \mu \mathrm{l})$ and stored at $-80^{\circ} \mathrm{C}$.

Transformation was conducted by adding $2 \mu \mathrm{l}$ plasmid to $100 \mu \mathrm{l}$ electro competent cells thawed on ice. Following $\sim 1$ min incubation on ice, electroporation was performed at 1.4 to $2.5 \mathrm{kV}$ (Eppendorf Eporator, Eppendorf AG, Hamburg, Germany or MicroPulser ${ }^{\mathrm{TM}}$, Bio-Rad, Hercules, CA), using $0.2 \mathrm{~cm}$ gap width electroporation cuvettes (Bio-Rad Laboratories, Hercules, CA). Before plating on selective LB-agar plates, cells were recovered in LB or S. O. C. medium (Invitrogen) at $37^{\circ} \mathrm{C}, 150$ $\mathrm{rpm}$, for 4 to $5 \mathrm{~h}$.

\section{Construction of $B$. licheniformis MW3 $\Delta$ gerAA::spc}

The shuttle vector used for construction of a spectinomycin resistant $\left(\mathrm{Sp}^{\mathrm{R}}\right)$ insertion deletion in the ger $A A$ was $\mathrm{pMAD} \_\mathrm{p}^{\mathrm{R}}$. This vector has been modified from pMAD [75] by insertion of a $\left(\mathrm{Sp}^{\mathrm{R}}\right)$-cassette in the restriction site SalI [76]. As selective antibiotics for the presence of pMAD_Sp ${ }^{R}$ or its derivative constructs, 100 $\mu \mathrm{g} / \mathrm{ml}$ ampicillin and $100 \mu \mathrm{g} / \mathrm{ml}$ spectinomycin was used for E. coli TOP10 growth, and $3 \mu \mathrm{g} / \mathrm{ml}$ erythromycin and $250-300 \mu \mathrm{g} / \mathrm{ml}$ spectinomycin for B. licheniformis growth. This vector carries a constitutively expressed $\beta$ galactosidase gene, allowing blue-white screening on plates spread with X-Gal $(40 \mu \mathrm{l} 40 \mathrm{mg} / \mathrm{ml} 5$-bromo-4chloro-3-indolyl- $\beta$-D-galactopyranoside, VWR, BDH Prolabo). This screening was, however, not always unambiguous following long incubations of plates with B. licheniformis MW3 transformants, probably due to the natural precence of $\beta$-galactosidase in $B$. licheniformis DSM 13 [77]. To construct the gene replacement vector, primers (Table 2) were designed to amplify two DNA fragments, one homologous to upstream (709 bp) and one to downstream (696 bp) regions of the deletion target (567 bp) in the gerAA. Platinum Taq DNA Polymerase High Fidelity kit (Invitrogen) was used for PCR amplification with the following amplification procedure: initial denaturation for $2 \mathrm{~min}$ at $94^{\circ} \mathrm{C}, 30$ cycles of $30 \mathrm{~s}$ at $94{ }^{\circ} \mathrm{C}, 30 \mathrm{~s}$ at $50{ }^{\circ} \mathrm{C}$ and $1 \mathrm{~min}$ at $68{ }^{\circ} \mathrm{C}$, and final extension at $68{ }^{\circ} \mathrm{C}$ for $10 \mathrm{~min}$. Primers of the upstream and downstream amplicons contained restriction sites BamHI and EcoRI respectively (Table 2), allowing a two_step ligation into the corresponding restriction sites on either side of the $\left(\mathrm{Sp}^{\mathrm{R}}\right)$-cassette in pMAD_Sp ${ }^{\mathrm{R}}$. The resulting gene replacement plasmid, pMAD_Sp ${ }^{\mathrm{R}} \Delta \operatorname{ger} A A$, was controlled for correct orientation of the upstream and downstream fragments by PCR. pMAD_Sp ${ }^{\mathrm{R}} \Delta \operatorname{ger} A A$ was introduced into $B$. licheniformis MW3 by electroporation, and allelic exchange of internal parts of ger $A A$ (567 bp) with the $\left(\mathrm{Sp}^{\mathrm{R}}\right)$-cassette of $\mathrm{pMAD} \_\mathrm{Sp}^{\mathrm{R}} \Delta$ ger $A A$ was allowed by double crossover. The protocol was performed as described by Arnaud et al.[75], except using growth temperatures of $37^{\circ} \mathrm{C}$ following initial transformation, an incubation temperature of $45^{\circ} \mathrm{C}$ and spectinomycin present during plasmid curing, and an incubation temperature of $37^{\circ} \mathrm{C}$ when screening for the double crossover phenotype (spectinomycin resistant and erythromycin sensitive colonies). Chromosomal DNA was purified from a candidate colony and used in PCR amplifications (as described above) with primers hybridizing outside the cloned DNA fragment and inside the spectinomycin cassette (Table 2) to verify the deletion and insertion by sequencing. The disruption mutant was named B. licheniformis MW3 3 gerAA::spc (NVH1307 ) and used in the following complementation, sporulation and germination assays.

\section{Construction of gerA complementation mutant}

The shuttle vector used as base for trans complementation of $\triangle$ gerAA::spc was pHT315 [52]. As selective antibiotics for presence of pHT315 constructs, $100 \mu \mathrm{g} / \mathrm{ml}$ ampicillin was used for $E$. coli TOP10 growth, while 1 $\mu \mathrm{g} / \mathrm{ml}$ erythromycin for $B$. licheniformis growth. Spectinomycin $(250 \mu \mathrm{g} / \mathrm{ml})$ was also supplemented for the chromosomal antibiotic resistance of NVH-1307 mutants carrying pHT315 derivatives (Table 1). To construct pHT315 complementation plasmids that harbour the gerA operon, DNA isolated from $B$. licheniformis MW3 was used. Primers, with SalI and XbaI restriction sites (Table 2) were designed to amplify a 3982 bp fragment spanning from $151 \mathrm{bp}$ upstream to $177 \mathrm{bp}$ downstream gerA (gerAA, gerAB, gerAC). To ensure high fidelity, PCR amplification was performed with Phusion Hot Start II High-Fidelity DNA Polymerase kit (Finnzymes). The amplification protocol was as follows; initial denaturation for $30 \mathrm{~s}$ at $98^{\circ} \mathrm{C}, 30$ cycles of $10 \mathrm{~s}$ at $98^{\circ} \mathrm{C}$, $30 \mathrm{~s}$ at $58{ }^{\circ} \mathrm{C}$ and $2 \mathrm{~min}$ at $72{ }^{\circ} \mathrm{C}$, and final extension at $72{ }^{\circ} \mathrm{C}$ for $10 \mathrm{~min}$. The amplified fragments were cloned into the SalI/XbaI restriction site of pHT315, giving the complementation plasmid pHT315_MW3gerA. The purified plasmid was controlled by sequencing using primers hybridizing to pHT315 and internal gerA. The verified plasmid was introduced into the disruption mutant (NVH-1307) by electroporation as described earlier, giving the strain $B$. licheniformis MW3 $\Delta$ gerAA:: spcpHT315_MW3gerA (NVH-1311). The strain was used in sporulation and germination assays.

\section{Sporulation}

Sporulation was performed by a modified version of the sporulation protocol and medium described by van der Voort [42] as outlined below. Bacteria were pre-cultivated for 5 to $6 \mathrm{~h}$ in $50 \mathrm{ml}$ LB-Broth with agitation (225 $\mathrm{rpm})$ at $50{ }^{\circ} \mathrm{C}$. Pre-culture of $\mathrm{NVH}-1307$ was supplemented with $250 \mu \mathrm{g} / \mathrm{ml}$ spectinomycin, while the culture of NVH-1311 was supplemented with $250 \mu \mathrm{g} / \mathrm{ml}$ 
Table 2 Primers used in this study

\begin{tabular}{|c|c|c|}
\hline primer name & sequence $^{a}$ & Application \\
\hline \multicolumn{3}{|c|}{ Primers used in the construction/verification of the disruption mutant (NVH-1307) } \\
\hline Upper $\triangle$ gerAA F BamHI & 5'- AATCGGATCCCAAGGAACACATCCATGAA-3' & Amplification of the upper fragment of pMAD_Sp $\Delta g e r A A^{b}$ \\
\hline Upper $\triangle$ gerAA R BamHI & 5'- TCAACAAAAATTGGGATCCGTCCATTAAA-3' & Amplification of the upper fragment of pMAD_Sp $\Delta g e r A A^{b}$ \\
\hline Lower $\triangle$ gerAA F EcoRl & 5'- TCTTCACCGAATTCGCTAGGCAAAGAA-3" & Amplification of the lower fragment of pMAD_Sp ${ }^{R} \Delta g e r A A^{b}$ \\
\hline Lower $\triangle$ gerAA R EcoRI & 5'- AAATGGA $\overline{A T T C A C C G T C A A A G C T C T G-3 ' ~}$ & Amplification of the lower fragment of pMAD_Sp ${ }^{\mathrm{R}} \triangle g e r A A^{b}$ \\
\hline Upper $\triangle$ gerAA F2 & 5'- TGAAAATTTCGCCAAACACT-3' & Verification/sequencing of $\mathrm{NVH}-1307^{b}$ \\
\hline specR R & 5'- TGATATGATCTITCATTTCCATAAAAC-3' & Verification/sequencing of $\mathrm{NVH}-1307^{c}$ \\
\hline Lower $\triangle$ gerAA R2 & 5'- TTCGGCAGAAACATCATCAG-3' & Verification/sequencing of $\mathrm{NVH}-1307^{b}$ \\
\hline specR F & 5'- ATTGAATGGACTAATGAAAATGTAAA-3' & Verification/sequencing of $\mathrm{NVH}-1307^{c}$ \\
\hline \multicolumn{3}{|c|}{ Primers used in the construction/verification of the complementation plasmid (pHT315gerA_MW3) } \\
\hline pHT315gerAwt_Sall F1 & 5'-CAATCTGTCGACGTTTCCCCGTAAGCCTGATT-3' & Amplification of the gerA fragment ${ }^{b, d}$ \\
\hline pHT315gerAwt_Xbal R1 & 5'-GTGAGGTCTAGACCGATCGTGAAGAAAAGCAT-3' & Amplification of the gerA fragment ${ }^{b, d}$ \\
\hline ASF & 5'AAAGAAGCCTTGGAGAAGTGA-3' & Verification/sequencing of pHT315gerA_MW3 ${ }^{b}$ \\
\hline AOR & 5'-CGCTTTGCCCTGGATATAGA-3' & Verification/sequencing of pHT315gerA_MW3 ${ }^{b}$ \\
\hline $4 \mathrm{AF}$ & 5'-CAATCCGCTAGGCCAGAC-3' & Verification/sequencing of pHT315gerA_MW3 ${ }^{b}$ \\
\hline $6 \mathrm{AF}$ & 5'-GCGGACTGAGCCTGAATATG-3' & Verification/sequencing of pHT315gerA_MW3 ${ }^{b}$ \\
\hline $8 \mathrm{AF}$ & 5'-CGCTCAGGATCCGTCTAAAG-3' & Verification/sequencing of pHT315gerA_MW3 ${ }^{b}$ \\
\hline A9F 2/8/15 & 5'-CAGATCGAAGCGCTGAATTT-3' & Verification/sequencing of pHT315gerA_MW3 ${ }^{b}$ \\
\hline pHT315R & 5'-GGAGAAAATACCGCATCAGG-3' & Verification/sequencing of pHT315gerA_MW3e \\
\hline
\end{tabular}

${ }^{a}$ The restriction sites are underlined and may differ in sequence from the template genome of Veith et. al.[48].

${ }^{b}$ The primer is complement to the genome of Veith et. al.[48].

'The primer is complement to the $S p^{R}$ cassette of pMAD_Sp ${ }^{R}$.

${ }^{d}$ The gerA fragment amplified contains a sequence $151 \mathrm{bp}$ upstream of gerAA, gerAA, gerAB, gerAC and 177 bp downstream of gerAC relative to the genome of Veith et. al.[48].

${ }^{e}$ The primer is complement to the pHT315 vector.

spectinomycin and $1 \mu \mathrm{g} / \mathrm{ml}$ erythromycin. Twenty $\mu \mathrm{l}$ of pre-culture was added to $100 \mathrm{ml}$ sporulation medium, containing $8 \mathrm{~g}$ of nutrient broth (Difco, Becton, Dickinson and Company, NJ, USA) per liter, $1 \mu \mathrm{M}$ FeS$\mathrm{O}_{4} \cdot 7 \mathrm{H}_{2} \mathrm{O}$ (Merck KGaA, Darmstadt, Germany), $2.5 \mu \mathrm{M}$ $\mathrm{CuCl}_{2} \cdot 2 \mathrm{H}_{2} \mathrm{O}$ (Sigma-Aldrich, Steinheim, Germany), 12.5 $\mu \mathrm{M} \mathrm{ZnCl}{ }_{2}$ (Sigma-Aldrich, Steinheim, Germany), $66 \mu \mathrm{M}$ $\mathrm{MnSO}_{4} \cdot 4 \mathrm{H}_{2} \mathrm{O}$ (BDH Prolabo, VWR International AS, Oslo, Norway), $1 \mathrm{mM} \mathrm{MgCl} 2 \cdot 6 \mathrm{H}_{2} \mathrm{O}$ (J. T. Baker Chemicals B. V., Deventer, Holland), $5 \mathrm{mM}\left(\mathrm{NH}_{4}\right)_{2} \mathrm{SO}_{4}$ (Merck KGaA, Darmstadt, Germany), $2.5 \mu \mathrm{M} \mathrm{Na}_{2} \mathrm{MoO}_{4} \cdot 2 \mathrm{H}_{2} \mathrm{O}$ (Riedel-de Häen, Sigma-Aldrich, Seelze, Germany), 2.5 $\mu \mathrm{M} \mathrm{CoCl}{ }_{2} \cdot 6 \mathrm{H}_{2} \mathrm{O}$ (Sigma-Aldrich, Steinheim, Germany) and $1 \mathrm{mM} \mathrm{Ca}\left(\mathrm{NO}_{3}\right)_{2} \cdot 4 \mathrm{H}_{2} \mathrm{O}$ (Merck KGaA, Darmstadt, Germany). Filter sterilised $\mathrm{Ca}\left(\mathrm{NO}_{3}\right)_{2} \cdot 4 \mathrm{H}_{2} \mathrm{O}$, $\mathrm{MnSO}_{4} \cdot 4 \mathrm{H}_{2} \mathrm{O}$ and $\mathrm{FeSO}_{4} \cdot 7 \mathrm{H}_{2} \mathrm{O}$ were added to the medium after it had been autoclaved. $\mathrm{pH}$ was adjusted to 7.6 before autoclaving, and the $\mathrm{pH}$ of the final sporulation medium was 7.2. Sporulation medium of NVH-1311 was supplemented with $1 \mu \mathrm{g} / \mathrm{ml}$ erythromycin. The cultures were incubated with agitation $(225 \mathrm{rpm})$ at $50{ }^{\circ} \mathrm{C}$ for 1 to 2 days for $B$. licheniformis strains MW3, NVH1307 and NVH-1311, or for 2 days at $30{ }^{\circ} \mathrm{C}$ for B. subtilis B252 and B. cereus ATCC 14579 until $\geq 90 \%$ phase bright spores as judged by phase contrast microscopy. Spores were harvested by centrifugation for $10 \mathrm{~min}$ at
$6000 \times g$ at $4{ }^{\circ} \mathrm{C}$, and resuspended in $10 \mathrm{ml}$ cold autoclaved MQ. Washing of spores was done by centrifugation and resuspension in MQ a total of ten times. The resulting spore crops, $<10 \%$ germinated spores, were stored refrigerated in MQ. When used in the following germination studies, spore crops were between 2 and 7 months old.

\section{Germination assays}

The spore suspension was routinely washed by centrifugation at $16.100 \times g$ for $3 \mathrm{~min}$ prior to each experiment [78]. Spores were heat activated in MQ at $65^{\circ} \mathrm{C}$ for 20 min, chilled on ice, centrifuged $(16.100 \times g$ for $3 \mathrm{~min})$ and resuspended in $2 \times$ germination buffer $(100 \mathrm{mM} \mathrm{K}$ phosphate buffer $\mathrm{pH}$ 7.2) for L-alanine germination or 1 $\times$ germination buffer $(50 \mathrm{mM}$ Tris $\mathrm{HCl} \mathrm{pH} 7.410 \mathrm{mM}$ $\mathrm{KCl}$ ) for germination with casein hydrolysate (Merck, Darmstadt, Germany). Casein hydrolysate consists of a mixture of different amino acids (Merck Microbiology Manual $12^{\text {th }}$ Edition: typical amino acid content (\% w/ w); alanine (2.00), arginine (2.20), aspartic acid (4.40), glutamic acid (12.50), glycine (1.20), histidine (1.80), isoleucine $(2.40)$, leucine $(3.40)$, lysine $(5.60)$, methionine (1.20), phenylalanine (2.50), proline (6.10), serine (2.70), threonine (2.20), tyrosine (0.60), valine (3.90)) made from acid hydrolyzation of the milk protein casein. 
Germination was followed as described by Hornstra et al.[13] by monitoring the reduction in absorbance at $\mathrm{A}_{600}$ as spores turn from phase-bright to phase dark at $30{ }^{\circ} \mathrm{C}$ in a 96 -well microplate in a plate reader (Tecan Intinite M200, Grödig, Austria). The spore suspension was adjusted to an initial $\mathrm{A}_{600}$ of $\sim 2$ (Shimadzu UV-VIS 160A, Shimadzu Europa GMBH) prior to addition of germinant. Germinant (filter sterilised L-alanine dissolved in MQ or casein hydrolysate dissolved in $50 \mathrm{mM}$ Tris $\mathrm{HCl} \mathrm{pH} \mathrm{7.4} 10 \mathrm{mM} \mathrm{KCl}$ ) or negative control (MQ for L-alanine germination and $50 \mathrm{mM}$ Tris $\mathrm{HCl} \mathrm{pH} 7.4$ $10 \mathrm{mM} \mathrm{KCl}$ for casein hydrolysate germination) was automatically injected, and the plate was shaken for $10 \mathrm{~s}$ prior to the first reading. $A_{600}$ was recorded every $30 \mathrm{~s}$ for 142 to $170 \mathrm{~min}$, with $10 \mathrm{~s}$ shaking in-between each measurement. The final concentration of germination buffer was $50 \mathrm{mM}$ phosphatebuffer $\mathrm{pH} 7.2$ or $50 \mathrm{mM}$ Tris $\mathrm{HCl} \mathrm{pH} \mathrm{7.4} 10 \mathrm{mM} \mathrm{KCl}$, and final concentration of germinant was $100 \mathrm{mM} \mathrm{L}$-alanine or $1 \%(\mathrm{w} / \mathrm{v})$ casein hydrolysate. The final concentration of spores gave an initial $\mathrm{A}_{600}$ of $\sim 0.7-0.8$. To inhibit germination with Lalanine and potential other amino acids in the casein hydrolysate germination assay, $0.2 \% \mathrm{D}$-alanine $(\mathrm{w} / \mathrm{v}$, final concentration) was in some experiments added to each test well. The germination progress was described as the percentage of the initial $\mathrm{A}_{600}\left(\% \mathrm{~A}_{600 \mathrm{i}}\right)$ for each measurement point [13]. All experiments were performed in duplicates on two individual spore batches and repeated at least twice. Germination was routinely controlled by phase-contrast microscopy (Olympus BX51, Hamburg, Germany) [13].

Spore germination in $\mathrm{Ca}^{2+}$-DPA was performed as follows; spores were washed in cold autoclaved MQ and resuspended in germination buffer $(125-250 \mathrm{mM}$ Tris base, 25-100 mM DPA (2,6-Pyridinedicarboxylic acid 99\%, Sigma-Aldrich, Steinheim, Germany) $\mathrm{pH} \sim 8$ ) [79]. Germination was initiated by addition of excess $\mathrm{CaCl}_{2} \cdot 2 \mathrm{H}_{2} \mathrm{O}$ (Riedel de Häen AG, Seelze, Germany), followed by incubation for $3 \mathrm{~h}$ with shaking at room temperature $\left(\sim 20^{\circ} \mathrm{C}\right)$. The final concentrations of $\mathrm{Ca}^{2}$ ${ }^{+}$-DPA in the assay were 20-80 mM DPA $30-100 \mathrm{mM}$ $\mathrm{CaCl}_{2}$, and the final concentration of spores gave an initial $\mathrm{A}_{600}$ of $~ 0.6-0.8$. Germination was described as an approximate percentage of phase dark spores after screening of microscopic slides by phase contrast microscopy $(100 \mathrm{x})$. Experiments were performed in duplicate on two individual spore batches and repeated at least twice.

\section{DNA sequencing and bioinformatics}

DNA sequencing was performed by GATC Biotech (Konstanz, Germany) or Source BioScience (Nottingham, United Kingdom). The genomic sequence of $B$. licheniformis DSM13 [48] was accessed at http://www. ncbi.nml.nih.gov [GenBank: AE017333].

\section{Acknowledgements and Funding}

We would like to thank Kristin O'Sullivan (Norwegian School of Veterinary Science, Oslo, Norway) for technical assistance and Dr Graham Christie (University of Cambridge, England) for sharing the pHT315 vector. The pMAD plasmid was a gift from Michel Débarbouillé (Institut Pasteur, Centre National de la Recherche Scientifique, Paris, France). The work has been financially supported by the Research Council of Norway (grant 178299/110).

\section{Author details}

${ }^{1}$ Nofima AS, Department of Process Technology, Måltidets hus, Richard Johnsens gate 4, P. Box 8034, N-4068 Stavanger, Norway. ${ }^{2}$ Departement of Food Safety and Infection Biology, Section for Food Safety, Norwegian School of Veterinary Science, Ullevålsveien 72, P. Box 8146 Dep., N-0033 Oslo, Norway. ${ }^{3}$ Forsvarets Forskningsinstiutt FFI, Norwegian Defence Research Establishment, P. O. Box 25, N-2027 Kjeller, Norway. ${ }^{4}$ Current address; University of Stavanger, Faculty of Arts and Education, Department of Early Childhood Education, N-4036 Stavanger, Norway. ${ }^{5}$ Current address; Mills DA, Sofienberggata 19, P. Box 4644, N-0506 Oslo, Norway.

\section{Authors' contributions}

ISL assisted in experimental design, carried out the experiments, analysed data and drafted the manuscript. CF assisted in experimental design, carried out the experiments, analysed data and assisted in drafting the manuscript. EHM assisted in drafting the manuscript. EK and KCSR carried out experiments. JTR assisted in drafting the manuscript. PEG assisted in experimental design and drafting of the manuscript. All authors read and approved the final manuscript.

Received: 22 December 2011 Accepted: 15 March 2012

Published: 15 March 2012

\section{References}

1. Setlow P: Spore germination. Curr Opin Microbiol 2003, 6:550-556.

2. Moir A, Smith DA: The genetics of bacterial spore germination. Ann Rev Microbiol 1990, 44:531-553.

3. Ross C, Abel-Santos E: The ger receptor family from sporulating bacteria. Curr Issues Mol Biol 2010, 12:147-157.

4. Hudson KD, Corfe BM, Kemp EH, Feavers IM, Coote PJ, Moir A: Localization of GerAA and GerAC germination proteins in the Bacillus subtilis spore. J Bact 2001, 183:4317-4322.

5. Paidhungat $M$, Setlow $P$ : Localization of a germinant receptor protein (GerBA) to the inner membrane of Bacillus subtilis spores. J Bact 2001, 183:3982-3990.

6. Moir A: How do spores germinate? J Appl Microbiol 2006, 101:526-530.

7. Griffiths KK, Zhang JQ, Cowan AE, Yu J, Setlow P: Germination proteins in the inner membrane of dormant Bacillus subtilis spores colocalize in a discrete cluster. Mol Microbiol 2011, 81:1061-1077.

8. Sammons RL, Moir A, Smith DA: Isolation and properties of spore germination mutants of Bacillus subtilis 168 deficient in the initiation of germination. J Gen Microbiol 1981, 124:229-241.

9. Clements MO, Moir A: Role of the gerl operon of Bacillus cereus 569 in the response of spores to germinants. J Bact 1998, 180:6729-6735.

10. Paidhungat $M$, Setlow $P$ : Role of ger proteins in nutrient and nonnutrient triggering of spore germination in Bacillus subtilis. J Bact 2000, 182:2513-2519.

11. Barlass PJ, Houston CW, Clements MO, Moir A: Germination of Bacillus cereus spores in response to $\mathrm{L}$ - alanine and to inosine: the roles of gerL and gerQ operons. Microbiology 2002, 148:2089-2095.

12. Ireland JAW, Hanna PC: Amino acid- and purine ribonucleoside-induced germination of Bacillus anthracis Delta Sterne endospores gerS mediates responses to aromatic ring structures. J Bact 2002, 184:1296-1303.

13. Hornstra LM, de Vries YP, de Vos WM, Abee T, Wells-Bennik MHJ: gerR, a novel ger operon involved in L-alanine- and inosine-initiated germination of Bacillus cereus ATCC 14579. Appl Environ Microbiol 2005, 71:774-781. 
14. Hornstra LM, de Vries YP, Wells-Bennik MHJ, de Vos WM, Abee T: Characterization of germination receptors of Bacillus cereus ATCC 14579. Appl Environ Microbiol 2006, 72:44-53.

15. Atluri S, Ragkousi K, Cortezzo DE, Setlow P: Cooperativity between different nutrient receptors in germination of spores of Bacillus subtilis and reduction of this cooperativity by alterations in the GerB receptor. J Bact 2006, 188:28-36.

16. Christie G, Lowe CR: Role of chromosomal and plasmid-borne receptor homologues in the response of Bacillus megaterium QM B1551 spores to germinants. J Bact 2007, 189:4375-4383.

17. Logan NA, De Vos P, et al: Genus I. Bacillus. In Bergey's manual of systematic bacteriology. Edited by: De Vos P, Garrity GM, Jones D, Krieg NR, Ludwig W, Rainey FA. New York: Springer; 2009:21-128.

18. Kalogridou-Vassiliadou D: Biochemical activities of Bacillus species isolated from flat sour evaporated milk. J Dairy Science 1992, 75:2681-2686.

19. Crielly EM, Logan NA, Anderton A: Studies on the Bacillus flora of milk and milk-products. J Appl Bacteriol 1994, 77:256-263.

20. Janstova B, Lukasova J: Heat resistance of Bacillus spp. spores isolated from cow's milk and farm environment. Acta Vet Brno 2001, 70:179-184.

21. Thompson JM, Waites WM, Dodd CER: Detection of rope spoilage in bread caused by Bacillus species. J Appl Microbiol 1998, 85:481-486.

22. Sorokulova IB, Reva ON, Smirnov W, Pinchuk IV, Lapa SV, Urdaci MC Genetic diversity and involvement in bread spoilage of Bacillus strains isolated from flour and ropy bread. Lett Appl Microbiol 2003, 37:169-173.

23. Bell RG, Delacy KM: A note on the identity and properties of the spoilage microflora of chub-packed luncheon meat stored at ambienttemperature. Can J Microbiol 1983, 29:1220-1223.

24. Fields ML, Zamora AF, Bradsher M: Microbiological analysis of homecanned tomatoes and green beans. J Food Science 1977, 42:931-934.

25. Eveleigh DE: The microbiological production of industrial chemicals. Sci Am 1981, 245:120-130.

26. de Boer AS, Priest F, Diderichsen B: On the industrial use of Bacillus licheniformis - A review. Appl Microbiol Biotechnol 1994, 40:595-598.

27. Schallmey M, Singh A, Ward OP: Developments in the use of Bacillus species for industrial production. Can J Microbiol 2004, 50:1-17.

28. Agerholm JS, Krogh HV, Jensen HE: A retrospective study of bovine abortions associated with Bacillus licheniformis. J Vet Med Series BInfectious Diseases and Veterinary Public Health 1995, 42:225-234.

29. Syrjälä P, Anttila M, Dillard K, Fossi M, Collin K, Nylund M, et al: Causes of bovine abortion, stillbirth and neonatal death in Finland 1999-2006. Acta Vet Scan 2007, 49:S3.

30. Santini F, Borghetti V, Amalfitano G, Mazzucco A: Bacillus licheniformis prosthetic aortic-valve endocarditis. J Clin Microbiol 1995, 33:3070-3073.

31. Tabbara KF, Tarabay N: Bacillus licheniformis corneal ulcer. Am J Ophthalmol 1979, 87:717-719.

32. Sugar AM, Mccloskey RV: Bacillus licheniformis sepsis. J Am Med Assoc 1977, 238:1180-1181.

33. Kramer JM, Gilbert RJ: Bacillus cereus and other Bacillus species. In Foodborne bacterial pathogens. Edited by: Doyle MP. New York: Marcel Dekker Inc; 1989:21-70

34. Salkinoja-Salonen MS, Vuorio R, Andersson MA, Kampfer P, Andersson MC, Honkanen-Buzalski T, et al: Toxigenic strains of Bacillus licheniformis related to food poisoning. Appl Environ Microbiol 1999, 65:4637-4645.

35. Mikkola R, Kolari M, Andersson MA, Helin J, Salkinoja-Salonen MS: Toxic lactonic lipopeptide from food poisoning isolates of Bacillus licheniformis. Eur J Biochem 2000, 267:4068-4074.

36. Errington J: Regulation of endospore formation in Bacillus subtilis. Nature Rev Microbiol 2003, 1:117-126.

37. Setlow P: Spores of Bacillus subtilis: their resistance to and killing by radiation, heat and chemicals. J Appl Microbiol 2006, 101:514-525.

38. Setlow $P$, Johnson EA: Spores and their significance. In Food microbiology: fundamentals and frontiers. Edited by: Doyle MP, Beuchat LR. Washington, DC: ASM Press; 2007:35-67.

39. Zuberi AR, Feavers IM, Moir A: Identification of 3 complementation units in the gerA spore germination locus of Bacillus subtilis. J Bact 1985, $162: 756-762$

40. Feavers IM, Miles JS, Moir A: The nucleotide sequence of a spore germination gene (gerA) of Bacillus subtilis 168. Gene 1985, 38:95-102.

41. Zuberi AR, Moir A, Feavers IM: The nucleotide-sequence and gene organization of the gerA spore germination operon of Bacillus subtilis 168. Gene 1987, 51:1-11.
42. van der Voort M, Garcia D, Moezelaar R, Abee T: Germinant receptor diversity and germination responses of four strains of the Bacillus cereus group. Int J Food Microbiol 2010, 139:108-115.

43. Paredes-Sabja D, Setlow P, Sarker MR: Germination of spores of Bacillales and Clostridiales species: mechanisms and proteins involved. Trends Microbiol 2011, 19:85-94.

44. Ross CA, Abel-Santos E: Guidelines for nomenclature assignment of Ger receptors. Res Microbiol 2010, 161:830-837.

45. Halmann $M$, Keynan A: Stages in germination of spores of Bacillus licheniformis. J Bact 1962, 84:1187-1193.

46. Martin JH, Harper WJ: Germination response of Bacillus licheniformis spores to amino acids. J Dairy Sci 1963, 46:663-667.

47. White $\mathrm{CH}$, Chang RR, Martin JH, Loewenst M: Factors affecting L- Alanine induced germination of Bacillus spores. J Dairy Sci 1974, 57:1309-1314.

48. Veith B, Herzberg C, Steckel S, Feesche J, Maurer KH, Ehrenreich P, et al: The complete genome sequence of Bacillus licheniformis DSM13, an organism with great industrial potential. J Mol Microbiol Biotechnol 2004, 7:204-211

49. Rey MW, Ramaiya P, Nelson BA, Brody-Karpin SD, Zaretsky EJ, Tang M, et al: Complete genome sequence of the industrial bacterium Bacillus licheniformis and comparisons with closely related Bacillus species. Gen Biol 2004, 5:R77.

50. Waschkau B, Waldeck J, Wieland S, Eichstadt R, Meinhardt F: Generation of readily transformable Bacillus licheniformis mutants. Appl Microbiol Biotechnol 2008, 78:181-188.

51. Cabrera-Martinez RM, Tovar-Rojo F, Vepachedu VR, Setlow P: Effects of overexpression of nutrient receptors on germination of spores of Bacillus subtilis. J Bact 2003, 185:2457-2464.

52. Arantes O, Lereclus D: Construction of cloning vectors for Bacillus thuringiensis. Gene 1991, 108:115-119.

53. Christie G, Gotzke H, Lowe CR: Identification of a receptor subunit and putative ligand-binding residues involved in the Bacillus megaterium QM B1551 spore germination response to glucose. J Bact 2010, 192:4317-4326.

54. Kunnimalaiyaan M, Stevenson DM, Zhou YS, Vary PS: Analysis of the replicon region and identification of an rRNA operon on pBM400 of Bacillus megaterium QM B1551. Mol Microbiol 2001, 39:1010-1021.

55. Powell JF: Factors affecting the germination of thick suspension of Bacillus subtilis spores in L- alanine solution. J Gen Microbiol 1950, 4:330-339.

56. Paidhungat M, Setlow P: Spore germination and outgrowth. In Bacillus subtilis and its closest relatives: From genes to cells. Edited by: Sonenshein AL, Hoch JA, Losick R. Washington, DC: American Society for Microbiology; 2002:537-548.

57. Setlow B, Peng L, Loshon CA, Li YQ, Christie G, Setlow P: Characterization of the germination of Bacillus megaterium spores lacking enzymes that degrade the spore cortex. J Appl Microbiol 2009, 107:318-328.

58. Zhang PF, Garner W, Yi XA, Yu J, Li YQ, Setlow P: Factors affecting variability in time between addition of nutrient germinants and rapid Dipicolinic acid release during germination of spores of Bacillus species. J Bact 2010, 192:3608-3619.

59. Kong LB, Zhang PF, Setlow P, Li YQ: Characterization of bacterial spore germination using integrated phase contrast microscopy, Raman spectroscopy, and optical tweezers. Anal Chem 2010, 82:3840-3847.

60. Pulvertaft RJV, Haynes JA: Adenosine and spore germination; phasecontrast studies. J Gen Microbiol 1951, 5:657-662.

61. Waites WM, Wyatt LR: The outgrowth of spores of Clostridium bifermentans. J Gen Microbiol 1974, 84:235-244.

62. Patel DC, Dave JM, Sannabhadti SS: Effect of selected heat treatments and added amino acids on germination response of bacterial spores in buffalo milk. Indian J Dairy Sci 1984, 37:93-97.

63. Griffiths MW, Hurvois Y, Phillips JD, Muir DD: Elimination of spore-forming bacteria from double cream using sub-UTH temperatures. II. Effect of processing conditions on spores. Milchwissenschaft-Milk Sci Int 1986, 41:474-478.

64. Hills GM: Chemical factors in the germination of spore-bearing aerobes: observations on the influence of species, strain and conditions of growth. J Gen Microbiol 1950, 4:38-47.

65. Halmann M, Keynan A: Stages in germination of spores of Bacillus licheniformis. J Bact 1962, 84:1187-1193. 
66. Yi XA, Setlow P: Studies of the commitment step in the germination of spores of Bacillus species. J Bact 2010, 192:3424-3433.

67. Paidhungat M, Ragkousi K, Setlow P: Genetic requirements for induction of germination of spores of Bacillus subtilis by Ca2+-Dipicolinate. J Bact 2001, 183:4886-4893.

68. Riemann H, Ordal ZJ: Germination of bacterial endospores with calcium and dipicolinic acid. Science 1961, 133:1703-1704.

69. Terry C, Shepherd A, Radford DS, Moir A, Bullough PA: YwdL in Bacillus cereus: Its role in germination and exosporium structure. Plos One 2011, 6:e23801.

70. Jaye M, Ordal ZJ: Germination of spores of Bacillus megaterium with divalent metal-dipicolinate chelates. J Bact 1965, 89:1617-1618.

71. From C, Pukall R, Schumann P, Hormazábal V, Granum PE: Toxin-producing ability among Bacillus spp. outside the Bacillus cereus group. Appl Environ Microbiol 2005, 71:1178-1183.

72. Frankland GC, Frankland PF: Studies on some new micro-organisms obtained from air. Phil Trans R Soc London B 1887, 178:257-287.

73. Ivanova N, Sorokin A, Anderson I, Galleron N, Candelon B, Kapatral V, et al: Genome sequence of Bacillus cereus and comparative analysis with Bacillus anthracis. Nature 2003, 423:87-91.

74. Mahillon J, Chungjatupornchai W, Decock J, Dierickx S, Michiels F, Peferoen $\mathrm{M}$, et al: Transformation of Bacillus thuringiensis by electroporation. FEMS Microbiol Lett 1989, 60:205-210.

75. Arnaud M, Chastanet A, Debarbouille M: New vector for efficient allelic replacement in naturally nontransformable, low-GC-content, grampositive bacteria. Appl Environ Microbiol 2004, 70:6887-6891.

76. Fagerlund A: Bacillus cereus $\mathrm{Hbl}$, Nhe and CytK cytotoxins. PhD thesis Norwegian School of Veterinary Science, Departement of Food Safety and Infection Biology; 2007.

77. Juajun $\mathrm{O}$, Nguyen TH, Maischberger T, labal S, Haltrich D, Yamabhai M: Cloning, purification, and characterization of beta-galactosidase from Bacillus licheniformis DSM 13. Appl Microbiol Biotechnol 2011, 89:645-654.

78. Nicholson WL, Setlow P: Sporulation, germination and outgrowth. In Molecular biological methods for Bacillus. Edited by: Harwood CR, Cutting SM. Chichester: John Wiley and Sons Inc; 1990:391-450

79. Vepachedu VR, Setlow P: Analysis of interactions between nutrient germinant receptors and SpoVA proteins of Bacillus subtilis spores. FEMS Microbiol Lett 2007, 274:42-47.

doi:10.1186/1471-2180-12-34

Cite this article as: Løvdal et al: Role of the gerA operon in L-alanine germination of Bacillus licheniformis spores. BMC Microbiology 2012 12:34.

\section{Submit your next manuscript to BioMed Central and take full advantage of:}

- Convenient online submission

- Thorough peer review

- No space constraints or color figure charges

- Immediate publication on acceptance

- Inclusion in PubMed, CAS, Scopus and Google Scholar

- Research which is freely available for redistribution

Submit your manuscript at www.biomedcentral.com/submit
C Biomed Central 